\title{
ASPEKTY KONSTYTUCYJNE AKADEMICKIEGO PROCESU TRANSFERU WIEDZY I TECHNOLOGII
}

\author{
Anna Deryng-Dziuk \\ Akademia im. Jana Długosza w Częstochowie \\ Zakład Prawa Konstytucyjnego i Ustroju Samorządu Terytorialnego \\ ,[...] dobry system to ten, \\ w którym świat biznesu przenika się ze światem edukacji \\ $i$ w którym edukacja nieformalna \\ może być wspierana i organizowana przez organizację formalna" \\ (Rogala 2013)
}

\begin{abstract}
Streszczenie: Celem artykułu jest prezentacja procesu akademickiego transferu wiedzy i technologii w świetle wybranych postanowień Konstytucji. Aspekty konstytucyjne akademickiego transferu wiedzy i technologii są zawarte w szczególności w art. 20 i 22 (zasady społecznej gospodarki rynkowej i swobody działalności gospodarczej), art. 64 (prawo do własności i innych praw majątkowych, dopuszczalnych ograniczeń prawa własności) i art. 73 (wolność twórczości artystycznej i badań naukowych) Konstytucji Rzeczypospolitej Polskiej.

Analiza materiałów badawczych dowodzi, iż dyskutowane postanowienia Konstytucji służą jako podstawy prawne akademickiego transferu wiedzy i technologii także $\mathrm{z}$ uwagi na to, iż wyznaczają podstawowe subiektywne i obiektywne elementy transferu. Postanowienia omówione i przedstawione w artykule wpływają również na ilościowe, jakościowe i funkcjonalne aspekty akademickiego transferu wiedzy i technologii.
\end{abstract}

Słowa kluczowe: akademicki transfer wiedzy i technologii, postanowienia konstytucyjne

DOI: $10.17512 /$ znpcz.2016.3.1.16

\section{Wprowadzenie}

Problematyka transferu wiedzy i technologii z uczelni wyższych do biznesu od dawna stanowi przedmiot zainteresowania praktyków, jak i teoretyków różnych dyscyplin naukowych (Derlukiewicz 2013, s. 247-256).

Celem niniejszego artykułu jest próba przedstawienia procesu transferu wiedzy $\mathrm{i}$ technologii $\mathrm{w}$ świetle wybranych przepisów konstytucyjnych. O ile bowiem procesy transferu wiedzy i technologii z uczelni wyższych do biznesu stają się tematem coraz popularniejszym, o tyle w polskiej literaturze nie powstały dotąd żadne publikacje czy opracowania naukowe, podejmujące problematykę ujęcia tych procesów z punktu widzenia Konstytucji Rzeczypospolitej Polskiej z dnia 2 kwietnia 1997 roku (dalej: Konstytucja RP, ustawa zasadnicza). Niniejszy artykuł stanowi próbę uzupełnienia tej luki. 
Wydaje się, że prezentacja aspektów konstytucyjnych akademickiego transferu wiedzy i technologii powinna w szczególności dotyczyć art. 20 i art. 22 Konstytucji RP (zasada społecznej gospodarki rynkowej i wolności działalności gospodarczej), art. 64 Konstytucji RP (prawo do własności i innych praw majątkowych; dopuszczalne ograniczenia prawa własności) oraz art. 73 Konstytucji RP (swoboda wyrazu twórczego i badań naukowych).

\section{Pojęcie akademickiego transferu wiedzy i technologii}

Transfer wiedzy i technologii definiowany jest jako proces, a nawet szereg procesów o pewnym stopniu złożoności, realizowany w określonym przedziale czasowym (Bromski 2013, s. 13). Kluczowym czynnikiem sprawczym i motorem napędowym transferu wiedzy i technologii są badania podstawowe i stosowane na uczelniach wyższych, a także ich wyniki w postaci produktów lub usług (Bromski 2013, s. 13). Analizując proces transferu wiedzy i technologii, niektórzy autorzy określają go jako „specyficzny krwiobieg” gospodarki opartej na wiedzy, na który składa się szereg elementów, tj.:

1) określone instytucje sfery nauki i badań (takie jak: instytuty naukowe, szkoły wyższe, centra badawcze, działy rozwojowe przedsiębiorstw, samodzielne laboratoria), które kreują podstawy zupełnie nowej wiedzy oraz rozwiązań technologicznych i organizacyjnych;

2) innowatorzy, czyli innowacyjni przedsiębiorcy, do grupy tej zalicza się także małe i średnie innowacyjne przedsiębiorstwa, które przeobrażają wiedzę czy innowacyjne pomysły w nowe produkty, technologie, a nawet usługi;

3) ośrodki innowacji, chodzi tu głównie o parki i inkubatory technologiczne, centra transferu technologii, preinkubatory czy akademickie inkubatory;

4) wyspecjalizowane fundusze finansowania innowacji w postaci funduszy kapitału zalążkowego, venture capital, anioły biznesu, które proponują specjalne narzędzia finansowania ryzyka związanego z procesami innowacyjnymi;

5) rynkowi dostawcy usług doradczych, szkoleniowych i informacyjnych (Matusiak, Guliński (red.) 2010, s. 13).

Zdaniem Małgorzaty Rybackiej pojęcie transferu technologii można rozpatrywać na dwóch płaszczyznach. Po pierwsze - jako dyfuzję innowacji wśród samych przedsiębiorstw (tzw. transfer poziomy). Po drugie - jako przepływ innowacji z sektora nauki do sektora przedsiębiorstw (tzw. transfer pionowy) (Rybacka 2013).

Natomiast, koncentrując się wyłącznie na procesie transferu wiedzy na uczelniach wyższych, w literaturze podkreśla się, iż występują dwa podstawowe kierunki tego procesu, tj. z uczelni do biznesu oraz z praktyki gospodarczej do uczelni (Derlukiewicz 2013, s. 252). Warto przy tym dodać, iż w przypadku transferu wiedzy z uczelni do biznesu wyróżnia się dwa przypadki transferu. Po pierwsze - szeroko pojęta edukacja studentów; po drugie - kooperacja z biznesem, np. poprzez różnego rodzaju badania (Derlukiewicz 2013, s. 252).

Niewątpliwie transfer wiedzy z uczelni wyższych do biznesu stanowi kluczowy czynnik decydujący o dalszym rozwoju uczelni. Bezsprzecznie jest to także jeden z kluczowych elementów determinujących rozwój gospodarczy. 
W ramach niniejszego artykułu skoncentruję się na transferze pionowym. Dla odróżnienia go od transferu poziomego używać będę przymiotnika „akademicki”, przy czym w niniejszym artykule przymiotnik ten będzie także oznaczał zawężenie pojęcia transferu do kierunku - z nauki (z uczelni) do biznesu.

\section{Akademicki transfer wiedzy i technologii w świetle wybranych przepisów Konstytucji RP z dnia 2 kwietnia 1997 r.}

Konstytucja Rzeczypospolitej Polskiej z dnia 2 kwietnia 1997 r. nie posługuje się pojęciem transferu wiedzy i technologii, nie używa określeń ,innowacyjny produkt” czy „dyfuzja innowacji”. Niemniej jednak z ogólnej liczby 243 artykułów ustawy zasadniczej, wskazać można te jej przepisy, które w pewien sposób oddziałują na procesy transferu wiedzy i technologii z uczelni wyższych do świata biznesu. W dalszej części opracowania nawiążę do tych przepisów Konstytucji RP, które w mojej ocenie są najistotniejsze dla przedstawienia konstytucyjnego aspektu akademickiego transferu wiedzy i technologii.

\section{Artykuł 20 i artykuł 22 Konstytucji RP}

Przedstawiając aspekt konstytucyjny akademickiego transferu wiedzy i technologii, w pierwszej kolejności wypada odnieść się do art. 20 i 22 Konstytucji RP. $\mathrm{W}$ pierwszym $\mathrm{z}$ tych przepisów ustrojodawca ustanowił zasadę społecznej gospodarki rynkowej jako podstawę ustroju gospodarczego RP (Garlicki 2005, s. 6; Karpiuk 2012, s. 35; Bernatt 2009, s. 111; Garlicki 2011, s. 75), nie podając przy tym jej definicji (Banaszak 2009, s. 125). Zgodnie z jego treścią: „Społeczna gospodarka rynkowa oparta na wolności działalności gospodarczej, własności prywatnej oraz solidarności, dialogu i współpracy partnerów społecznych stanowi podstawę ustroju gospodarczego Rzeczypospolitej Polskiej”. Artykuł ten wraz $\mathrm{z}$ postanowieniami wynikającymi $\mathrm{z}$ treści art. 21, 22, 23 oraz 24 ustawy zasadniczej określają podstawowe ramy ustroju gospodarczego RP (Winczorek 2000, s. 32). Jak podaje Bogusław Banaszak, „samo pojęcie społecznej gospodarki rynkowej zostało przejęte do polskiej ustawy zasadniczej $\mathrm{z}$ dorobku konstytucjonalizmu rozwiniętych państw demokratycznych, a zwłaszcza Niemiec" (Banaszak 2008, s. 244).

W doktrynie prawa konstytucyjnego podkreśla się, iż termin ten nie ma jednej, powszechnej definicji, brak jej jest również w orzecznictwie sądowym (Banaszak 2009, s. 125). Zdaniem Cezarego Kosikowskiego ,zasada społecznej gospodarki rynkowej nie jest dostatecznie dostrzegana w praktyce, dla której zasada ta ma głównie wydźwięk doktrynalny. Może to świadczyć jedynie o tym, jak wciąż małe jest zrozumienie istoty społecznej gospodarki rynkowej jako zasady konstytucyjnej” (Kosikowski 2005, s. 57).

Podobnie wygląda sytuacja w przypadku pojęcia działalności gospodarczej. Również w tym przypadku ustawa zasadnicza nie wyjaśnia tego terminu. Czyni to dopiero ustawa z dnia 2 lipca 2004 r. o swobodzie działalności gospodarczej (Dz.U. 2015 poz. 584, z późn. zm.), która $\mathrm{w}$ art. 2 podaje następującą definicję działalności 
gospodarczej: „Działalnością gospodarczą jest zarobkowa działalność wytwórcza, budowlana, handlowa, usługowa oraz poszukiwanie, rozpoznawanie i wydobywanie kopalin ze złóż, a także działalność zawodowa, wykonywana w sposób zorganizowany i ciągły". Dokonując analizy konstytucyjnej zasady społecznej gospodarki rynkowej, wskazać można na podstawowe elementy gospodarki rynkowej. Zdaniem Bogusława Banaszaka katalog ten może być różnie określany, niemniej obejmuje on pewne minimum, do którego należą: własność prywatna, wolność gospodarcza (art. 22 Konstytucji RP) i związana z nią wolność umów, wolna konkurencja, a także kształtowanie cen za pomocą mechanizmów rynkowych, wolność pracy, wolny przepływ pracowników, kapitału i usług oraz swoboda i samodzielność podejmowania decyzji gospodarczych (Banaszak 2009, s. 125).

Z kolei, w ocenie Wiesława Skrzydło, art. 20 ustawy zasadniczej określa podstawowe zasady ustroju gospodarczego RP (Skrzydło 2002, s. 31-32). Do zasad tych zalicza:

1) „budowanie społecznej gospodarki rynkowej, a więc gospodarki, która uwzględnia społeczne aspekty jej funkcjonowania;

2) wolność prowadzenia działalności gospodarczej - nie przewidziano żadnych jej ograniczeń;

3) przyznanie prymatu sektorowi prywatnemu w gospodarce, czyli uznanie własności prywatnej za podstawę życia gospodarczego;

4) dialog i współpraca partnerów społecznych" (Skrzydło 2002, s. 32).

Natomiast art. 22 ustawy zasadniczej wprost wskazuje, że „ograniczenie wolności działalności gospodarczej jest dopuszczalne tylko w drodze ustawy i tylko ze względu na ważny interes publiczny”. Z powyższego wynika, że „ograniczenia te wynikać muszą z obowiązku spełnienia przewidzianych prawem warunków prowadzenia działalności gospodarczej" (Banaszak 2009, s. 135), czyli są wprowadzane w drodze wyjątku (Winczorek 2000, s. 33) i nie mogą być interpretowane w sposób rozszerzający (Karpiuk 2012, s. 36). Chodzi tu w szczególności o regulacje prawne dotyczące ochrony przed zagrożeniem życia i zdrowia ludzkiego, a także o spełnienie określonych wymagań wskazanych w przepisach budowlanych, sanitarnych, przeciwpożarowych i w przepisach dotyczących ochrony środowiska (Banaszak 2009, s. 135).

Zdaniem Bogusława Banaszaka „prawne ograniczenie swobody działalności gospodarczej związane jest $\mathrm{z}$ interwencjonizmem państwowym. Ma ono na celu przeciwdziałanie powstawaniu monopoli, będących zaprzeczeniem gospodarki wolnorynkowej" (Banaszak 2009, s. 136). W doktrynie prawa konstytucyjnego podkreśla się także, że „[...] z art. 22 można wyprowadzać obowiązki władz publicznych wykraczające poza tradycyjny zakres regulacji „władza a jednostka”. „[...] Gdy art. 22 występuje tylko w charakterze zasady ustroju, nie można z niego wyprowadzać roszczeń podmiotów indywidualnych wobec władz publicznych. Konstrukcja roszczenia indywidualnego związana jest bowiem wyłącznie z prawami podmiotowymi" (Garlicki 2005a, s. 7).

Warto przy tym wspomnieć, że omawiany przepis dopuszcza jedynie ograniczenie wolności działalności gospodarczej, a nie jej zniesienie (Winczorek 2000, s. 35). Jak słusznie zauważa przy tym Piotr Winczorek, „stopień dozwolonego 
ograniczenia nie jest tu określony. Można jedynie założyć, że nie może ono być posunięte tak daleko, by praktycznie niweczyć samą istotę tej wolności" (Winczorek 2000, s. 35).

Zaprezentowana konstytucyjna zasada społecznej gospodarki rynkowej stanowi niewątpliwie fundament transferu wiedzy i technologii. Wyznacza w sposób najbardziej pierwotny podstawowe elementy układu podmiotowego, w którym następować może przepływ wiedzy i technologii. Bez tej konstytucyjnej zasady i jej rozwinięcia w ustawodawstwie zwykłym trudno sobie wyobrazić legalne funkcjonowanie w systemie gospodarczym sektora prywatnego. Sektor ten stanowi bowiem konieczny element układu podmiotowego, w ramach którego możliwym staje się przepływ wiedzy i technologii.

Zasada społecznej gospodarki rynkowej, jej rozumienie i związana z tym metoda jej odkodowania na poziomie ustawodawstwa zwykłego w istotny sposób oddziałuje w praktyce na rozmiar sektora prywatnego w systemie gospodarczym. $\mathrm{Z}$ kolei rozmiar ten bezpośrednio oddziałuje na zakres akademickiego transferu wiedzy i technologii. W konsekwencji zasada społecznej gospodarki rynkowej istotnie oddziałuje na parametry ilościowe tego transferu.

Konstytucyjna zasada społecznej gospodarki rynkowej wyznacza także zręby funkcjonalne transferu wiedzy i technologii. Wolność gospodarcza i związana z nią wolność umów, wolność przepływu usług, swoboda i samodzielność podejmowania decyzji gospodarczych stanowią niejako warunki progowe, bez których transfer wiedzy i technologii już z samego założenia nie mógłby zafunkcjonować. Ponadto omawiana tutaj zasada oddziałuje na przebieg procesu transferu i sposób jego funkcjonowania. Oddziaływanie konstytucyjnej zasady społecznej gospodarki rynkowej ma zatem z punktu widzenia akademickiego transferu wiedzy i technologii aspekt jakościowy.

\section{Artykul 64 Konstytucji RP}

Kontekst konstytucyjny akademickiego transferu wiedzy i technologii pojawia się także w odniesieniu do konstytucyjnej zasady ochrony własności. Zgodnie z art. 64 Konstytucji RP: „1. Każdy ma prawo do własności, innych praw majątkowych oraz prawo dziedziczenia. 2. Własność, inne prawa majątkowe oraz prawo dziedziczenia podlegają równej dla wszystkich ochronie prawnej. 3. Własność może być ograniczona tylko $\mathrm{w}$ drodze ustawy i tylko $\mathrm{w}$ zakresie, $\mathrm{w}$ jakim nie narusza ona istoty prawa własności”. Regulacja ta pozostaje w związku z art. 21 ustawy zasadniczej, stanowiącym, że: „1. Rzeczpospolita Polska chroni własność i prawo dziedziczenia. 2. Wywłaszczenie jest dopuszczalne jedynie wówczas, gdy jest dokonywane na cele publiczne i za słusznym odszkodowaniem". A także z treścią art. 165 ustawy zasadniczej, stanowiącego, że: „1. Jednostki samorządu terytorialnego mają osobowość prawną. Przysługują im prawo własności i inne prawa majątkowe. 2. Samodzielność jednostek samorządu terytorialnego podlega ochronie sądowej".

Jak wskazuje Wiesław Skrzydło, „Artykuł 64 traktuje własność szeroko, wymienia także inne prawa majątkowe, którym poręcza prawo ich dziedziczenia" (Skrzydło 2002, s. 78). Jeśli chodzi o zakres podmiotowy praw gwarantowanych 
w art. 64 ust. 1 ustawy zasadniczej również jest określony szeroko i obejmuje zarówno osoby fizyczne, jak i osoby prawne (Banaszak 2009, s. 331). Warto przy tym dodać, na co zwrócił uwagę Leszek Garlicki, iż Konstytucja RP nie wyjaśnia zarówno pojęcia, jak i zakresu „prawa własności” (Garlicki 2003, s. 7). Tym samym wyraźnie wskazuje na nawiązanie do cywilistycznego ich rozumienia (Garlicki 2003, s. 7). Podobnie podkreśla Marek Safjan, twierdząc, że „cywilistyczne postrzeganie własności jest (powinno być) coraz silniej warunkowane spojrzeniem na własność jako prawo fundamentalne, posiadające rzeczywiste gwarancje konstytucyjne, których wymiar nie może być już sprowadzony do czystej ideologii i polityki. [...] W czysto formalnym ujęciu własności (częstym w płaszczyźnie cywilistycznej) tkwi bowiem pułapka. Ujęcie pozbawione odniesienia zewnętrznego, wyznaczającego granice ingerencji ustawodawczej pozwoli każdą jej postać uznać za usprawiedliwioną" (Jarosz-Żukowska 2003, s. 34 oraz przywołana tam literatura).

W literaturze podkreśla się, iż analiza określonych przepisów ustawy zasadniczej, tj. art. 20, art. 21, a także art. 64 i art. 175, pozwala na wyjaśnienie rozumienia pojęcia „własności” w dwóch ujęciach (Jarosz-Żukowska 2003, s. 36). Po pierwsze - jako synonim mienia, o czym traktuje art. 20 i 21 Konstytucji RP. Po drugie - jako składnik mienia, czyli prawo własności jest tożsame $\mathrm{z}$ jednym z podmiotowych praw majątkowych (art. 64 i art. 165 Konstytucji RP) (Jarosz-Żukowska 2003, s. 36).

Przywołana w tym miejscu konstytucyjna zasada poszanowania własności stanowi, podobnie jak wcześniej omówiona zasada społecznej gospodarki rynkowej, istotny element fundamentu transferu wiedzy i technologii. Jednak ma ona przede wszystkim aspekt przedmiotowy. Wyznacza bowiem w sposób pierwotny podstawowe elementy o charakterze przedmiotowym tego transferu. Do zaistnienia transferu wiedzy i technologii konieczne są nie tylko podmioty, pomiędzy którymi taki transfer może mieć miejsce, ale także przedmiot, którego transfer będzie dotyczył, tj. substrat przepływu. Wiedza i technologia nie mogłaby zostać objęta transferem, gdyby wcześniej ustawodawca konstytucyjny, a potem ustawodawca zwykły nie skonstruował pojęcia własności i wyznaczył ramy tego pojęcia poprzez zagwarantowanie ochrony prawa własności. $Z$ kolei sposób rozumienia pojęcia własności wyznaczony w pierwszej kolejności przez ustawodawcę konstytucyjnego oraz determinowany przez przepisy konstytucyjne charakter prawny instrumentów ochrony własności w istotny sposób oddziałuje na rozumienie pojęć wiedzy i technologii jako substratu transferu. Oddziaływanie tej zasady dotyczy zatem parametrów jakościowych transferu, w zakresie instrumentów ochrony własności, dotyczy także parametrów funkcjonalnych tego procesu.

\section{Artykuł 73 Konstytucji RP}

Prezentując konstytucyjny kontekst akademickiego transferu wiedzy i technologii nie sposób pominąć art. 73 Konstytucji RP. Zgodnie z tym przepisem „Każdemu zapewnia się wolność twórczości artystycznej, badań naukowych oraz ogłaszania ich wyników, wolność nauczania, a także wolność korzystania z dóbr kultury" (Skrzydło 2002, s. 88). W literaturze przedmiotu słusznie podnosi się, że 
przepis ten pozostaje w bliskim związku ze wstępem do Konstytucji RP (ochrona i pomnożenie kulturalnego dziedzictwa narodu) (Winczorek 2000, s. 97), a także $\mathrm{z}$ art. 6 (zasada dostępu do narodowego dziedzictwa kulturowego), art. 14 (zasada wolności środków społecznego przekazu), art. 35 (ochrona mniejszości narodowych), art. 53 (wolność sumienia i religii), art. 54 (wolność wypowiedzi; zakaz cenzury prewencyjnej i koncesjonowania prasy), art. 70 (prawo do nauki i obowiązek nauki) i art. 71 (zasada uwzględniania dobra rodziny w polityce społecznej i gospodarczej) Konstytucji RP (Bułajewski, Dąbrowski 2006, s. 229; Winczorek 2000, s. 97).

Postanowienie art. 73 Konstytucji RP wskazuje na dwa typy wolności. Po pierwsze - wolności twórców dzieł artystycznych i naukowych oraz nauczycieli. Po drugie - wolności osób będących odbiorcami dóbr kultury, w tym także osób pobierających naukę (Winczorek 2000, s. 97). Istotnym jest, na co zwraca uwagę Piotr Winczorek, aby „oba te typy wolności są (były) przez Konstytucję chronione w jednakowym stopniu" (Winczorek 2000, s. 97).

Zdaniem Mariusza Jabłońskiego art. 73 ustawy zasadniczej obejmuje szereg gwarancji swobodnego działania przyznanych każdemu (Jabłoński 2002, s. 552). Chodzi tym samym o możliwość: prowadzenia działalności twórczej, w tym artystycznej, naukowej i technicznej; ogłaszania swoich wyników badań; nauczania, a także korzystania z dóbr kultury (Jabłoński 2002, s. 552). W rezultacie autor ten wyróżnia aż pięć wolności, tj.: wolność twórczości artystycznej (wolność sztuki); wolność badań naukowych; wolność ogłaszania wyników działalności twórczej; wolność nauczania czy wolność korzystania z dóbr kultury (Jabłoński 2002, s. 552).

Należy przy tym zwrócić uwagę, że praktycznie wszystkie wyżej wymienione wolności (za wyjątkiem wolności korzystania z dóbr kultury) pozostają w bliskim związku z art. 54 ustawy zasadniczej, stanowiącym, że „1. Każdemu zapewnia się wolność wyrażania swoich poglądów oraz pozyskiwania i rozpowszechniania informacji. 2. Cenzura prewencyjna środków społecznego przekazu oraz koncesjonowanie prasy są zakazane. Ustawa może wprowadzić obowiązek uprzedniego uzyskania koncesji na prowadzenie stacji radiowej lub telewizyjnej" (Garlicki 2003a, s. 2). W doktrynie prawa podkreśla się, że z jednej strony ,[...] do interpretacji tych wolności można stosować ogólne konstrukcje i ustalenia odnoszące się do wolności wyrażania poglądów [...]”, ,a z drugiej - że skoro art. 73 gwarantuje odrębnie te wolności, to przyznaje im szczególne znaczenie i nakazuje zapewnienie im szczególnie silnej ochrony" (Garlicki 2003a, s. 2).

Warto w tym miejscu wskazać na kolejne powiązanie art. 73 Konstytucji RP z przywołanym powyżej art. 20 ustawy zasadniczej, proklamującym zasadę społecznej gospodarki rynkowej i wolności gospodarczej, oraz z art. 64 Konstytucji RP, wyrażającym prawo do własności i innych praw majątkowych. Ustawa zasadnicza $\mathrm{w}$ art. $21 \mathrm{i}$ art. 64 zapewnia jedynie ochronę praw majątkowych twórcy (Jabłoński 2002, s. 554-555). Natomiast w żaden sposób nie odnosi się do kwestii praw niemajątkowych twórcy, a podstaw ich ochrony należy poszukiwać $\mathrm{w}$ innych przepisach ustawy zasadniczej (Jabłoński 2002, s. 554-555). Zwrócił na to uwage Mariusz Jabłoński, twierdząc, że „brak jest bowiem jednoznacznie określonej za- 
sady dającej twórcom możliwość dochodzenia ich praw o charakterze niemajątkowym" (Jabłoński 2002, s. 555).

Jeśli chodzi o zakres podmiotowy omawianej wolności, to uznać można, dokonując analizy art. 73 ustawy zasadniczej, że przysługuje ona „każdemu”. Rozwiązanie takie sugeruje, że regulacja ta skierowana jest zarówno do obywateli polskich, jak i cudzoziemców (Garlicki 2003a, s. 3) oraz bezpaństwowców (Sobczak 2008, s. 111). W doktrynie podkreśla się, iż nie dotyczy ona osób prawnych (Garlicki 2003a, s. 3). Twórczość artystyczna jest bowiem wynikiem określonej działalności człowieka bądź też pewnej grupy ludzi (Garlicki 2003a, s. 3). Tym samym osoby prawne, szkoły wyższe czy różnego rodzaju instytuty naukowe, instytucje gospodarcze inicjujące i prowadzące tego typu badania nie są adresatami tej wolności.

W przypadku natomiast wolności sztuki można „mówić o pośrednim oddziaływaniu wolności twórczości artystycznej na ochronę swobody działania takich podmiotów prawnych, jak muzea, teatry, wytwórnie filmowe itp. [...]" (Garlicki 2003a, s. 4).

Odnosząc treść art. 73 Konstytucji RP do akademickiego transferu wiedzy i technologii, zasadnym jest skoncentrowanie się przede wszystkim na wynikającej z tego przepisu wolności badań naukowych i wolności ogłaszania wyników badań naukowych. W odniesieniu do pozostałych treści tego przepisu konstytucyjnego ze względu na ramy niniejszego artykułu koniecznym jest ograniczyć się do przedstawionej powyżej sygnalizacji, $\mathrm{z}$ uwypukleniem ich wzajemnych powiązań. Dostrzec również należy ich powiązania $\mathrm{z}$ zaprezentowanymi wcześniej zasadami społecznej gospodarki rynkowej i wolności gospodarczej, a także ochrony własności.

Konstytucyjna wolność badań naukowych i ogłaszania ich wyników ma, podobnie jak przedstawione powyżej zasady konstytucyjne, znaczenie fundamentalne dla akademickiego transferu wiedzy i technologii. Bez zagwarantowania poszanowania tej wolności proces transferu wiedzy i technologii nie mógłby zaistnieć wobec braku przedmiotu takiego transferu.

Bez tej wolności trudno także wyobrazić sobie funkcjonowanie po stronie akademickiej podmiotów transferujących wiedzę i technologię do podmiotów biznesowych.

Oddziaływanie wolności badań naukowych i ogłaszania ich wyników dotyczy parametrów ilościowych, jak i jakościowych transferu. Niemniej oddziaływanie w tym zakresie nie zawsze skutkować będzie wzrostem ilościowym lub jakościowym transferu. Omawiane tutaj wolności mogą mieć bowiem charakter ograniczający transfer. Wolność badań naukowych obejmuje także prawo do prowadzenia badań, które z założenia nie będą podlegały transferowi, przede wszystkim ze względu na brak zainteresowania ze strony podmiotów biznesowych. Co więcej, wolność badań dopuszcza priorytetowe potraktowanie badań nietransferowalnych nawet kosztem ograniczenia prowadzenia badań, co do których podmioty biznesowe zgłaszają zainteresowanie. Odwracając natomiast perspektywę, „przymus” transferu wiedzy i technologii może istotnie ograniczyć wolność badań naukowych i skutkować prowadzeniem wyłącznie badań objętych zapotrzebowaniem ze strony podmiotów biznesowych. Relacja pomiędzy wolnością badań naukowych i wolnością ich publikacji a akademickim transferem wiedzy i technologii będzie miała 
wówczas charakter konfliktowy. W tym aspekcie transfer wiedzy i technologii może stać się niekonstytucyjny, a poszczególne regulacje prawne dotyczące tego transferu mogą być uznane za niezgodne z Konstytucją RP.

\section{Podsumowanie}

Konkludując, stwierdzić można, iż omówione dotychczas przepisy konstytucyjne mają charakter swoistych fundamentów prawnych, na których opiera się akademicki transfer wiedzy i technologii. Regulacje te wyznaczają bowiem podstawowe elementy podmiotowe oraz przedmiotowe tego transferu. Udzielając odpowiedzi na pytanie: kto jest podmiotem akademickiego transferu wiedzy i technologii oraz co jest przedmiotem tego procesu, nie sposób pominąć regulacji konstytucyjnych.

Oddziaływanie omówionych przepisów Konstytucji RP dotyczy także aspektów: ilościowego, jakościowego oraz funkcjonalnego akademickiego transferu wiedzy i technologii. Powyższe sprawia, że przedstawione powyżej przepisy ustawy zasadniczej stanowić będą punkt odniesienia przy ocenie konstytucyjności regulacji prawnych dotyczących akademickiego transferu wiedzy i technologii na poziomie ustawowym.

\section{Literatura}

1. Banaszak B. (2008), Prawo konstytucyjne, C.H. Beck, Warszawa.

2. Banaszak B. (2009), Konstytucja Rzeczypospolitej Polskiej. Komentarz, C.H. Beck, Warszawa.

3. Bernatt M. (2009), Społeczna odpowiedzialność biznesu. Wymiar konstytucyjny i międzynarodowy, Wydział Zarządzania Uniwersytetu Warszawskiego, Warszawa.

4. Bromski K. (2013), Transfer wiedzy i technologii z uczelni do biznesu. Przewodnik po możliwościach wsparcia i dobrych praktyk, [w:] Transfer technologii - przewodnik po dobrych praktykach. Zbiór publikacji ekspertów Rady Programowej Dolnoślaskiego Ośrodka Transferu Wiedzy i Technologii, Dolnośląski Ośrodek Transferu Wiedzy i Technologii, Wrocław.

5. Bułajewski S., Dąbrowski M. (2006), Rozdział siódmy. Wolności i prawa ekonomiczne, socjalne i kulturalne, [w:] Chmaj M. (red.), Wolności i prawa człowieka w Konstytucji Rzeczypospolitej Polskiej, Wolters Kluwer, Kraków.

6. Derlukiewicz N. (2013), Transfer wiedzy z uczelni wyższych do gospodarki. Podejście systemowe, [w:] Transfer technologii - przewodnik po dobrych praktykach. Zbiór publikacji ekspertów Rady Programowej Dolnośląskiego Ośrodka Transferu Wiedzy i Technologii, Dolnośląski Ośrodek Transferu Wiedzy i Technologii, Wrocław.

7. Garlicki L. (2003), Artykut 64, [w:] Garlicki L. (red.), Konstytucja Rzeczypospolitej Polskiej. Komentarz, t. 3, Sejm Rzeczypospolitej Polskiej, Warszawa.

8. Garlicki L. (2003a), Artykut 74, [w:] Garlicki L. (red.), Konstytucja Rzeczypospolitej Polskiej. Komentarz, t. 3, Sejm Rzeczypospolitej Polskiej, Warszawa.

9. Garlicki L. (2005), Artykut 20, [w:] Garlicki L. (red.), Konstytucja Rzeczypospolitej Polskiej. Komentarz, t. 4, Sejm Rzeczypospolitej Polskiej, Warszawa.

10. Garlicki L. (2005a), Artykut 22, [w:] Garlicki L. (red.), Konstytucja Rzeczypospolitej Polskiej. Komentarz, t. 4, Sejm Rzeczypospolitej Polskiej, Warszawa.

11. Garlicki L. (2011), Polskie prawo konstytucyjne. Zarys wykładu, Wolters Kluwer, Warszawa. 
12. Jabłoński M. (2002), Wolności z art. 73 Konstytucji RP, [w:] Banaszak B., Preisner A. (red.), Prawa $i$ wolności obywatelskie w Konstytucji RP, C.H. Beck, Warszawa.

13. Jarosz-Żukowska S. (2003), Konstytucyjna zasada ochrony własności, Kantor Wydawniczy Zakamycze, Kraków.

14. Karpiuk M. (2012), Zasady ustroju politycznego państwa w Rzeczypospolitej Polskiej, [w:] Bożek M., Karpiuk M., Kostrubiec J., Walczuk K., Zasady ustroju politycznego państwa, Iuris, Poznań.

15. Konstytucja Rzeczypospolitej Polskiej z dnia 2 kwietnia 1997 r. uchwalona przez Zgromadzenie Narodowe w dniu 2 kwietnia 1997 r., przyjęta przez Naród w referendum konstytucyjnym w dniu 25 maja 1997 r., podpisana przez Prezydenta Rzeczypospolitej Polskiej w dniu 16 lipca 1997 r. (Dz.U. 1997 nr 78 poz. 483, późn. zm.).

16. Kosikowski C. (2005), Publiczne prawo gospodarcze Polski i Unii Europejskiej, LexisNexis, Warszawa.

17. Matusiak K.B., Guliński J. (red.) (2010), Rekomendacje zmian w polskim systemie transferu technologii i komercjalizacji wiedzy, PARP, Warszawa.

18. Rogala B. (2013), Firma jako uniwersytet, „Pomorski Przegląd Gospodarczy” (2013), http://ppg.ibngr.pl/pomorski-przeglad-gospodarczy/firma-jako-uniwersytet (dostęp: 11.06.2016).

19. Rybacka M. (2013), Kanaty transferu wiedzy i technologii z sektora nauki do gospodarki, „Pomorski Przegląd Gospodarczy”, http://ppg.ibngr.pl/pomorski-przeglad-gospodarczy/ kanaly-transferu-wiedzy-i-technologii-z-sektora-nauki-do-gospodarki (dostęp: 11.06.2016).

20. Skrzydło W. (2002), Konstytucja Rzeczypospolitej Polskiej. Komentarz, Kantor Wydawniczy Zakamycze, Kraków.

21. Sobczak J. (2008), Wolność badań naukowych - złudzenia a rzeczywistość, [w:] Gardocka T., Sobczak J. (red.), Dylematy praw człowieka, Wydawnictwo Adam Marszałek, Torun.

22. Ustawa z dnia 2 lipca 2004 r. o swobodzie działalności gospodarczej (Dz.U. 2004 nr 173 poz. 1807 , z późn. zm.).

23. Winczorek P. (2000), Komentarz do Konstytucji Rzeczypospolitej Polskiej z dnia 2 kwietnia $1997 r$., Liber, Warszawa.

\title{
CONSTITUTIONAL ASPECTS OF ACADEMIC KNOWLEDGE AND TECHNOLOGY TRANSFER
}

\begin{abstract}
The objective of this paper is to present the process of academic knowledge and technology transfer in light of selected provisions of the Constitution. The constitutional aspects of the academic knowledge and technology transfer are embodied, in particular, in Arts. 20 and 22 (the principle of social market economy and freedom of economic activity), Art. 64 (right of ownership and other property rights; permissible restrictions of the right of ownership), and Art. 73 (freedom of artistic creation and scientific research) of the Constitution of the Republic of Poland.

Analysis of the research materials proves that the discussed provisions of the Constitution serve as legal foundations on which the academic knowledge and technology transfer is established. This is so because the relevant regulations mark the basic subjective and objective elements of the transfer. The constitutional provisions discussed in the paper also influence the quantitative, qualitative and functional aspects of the academic knowledge and technology transfer.
\end{abstract}

Keywords: academic, knowledge and technology transfer, constitutional provisions 